\title{
Månedens mineral \\ - beryl
}

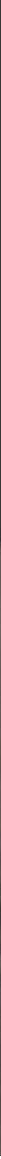

Månedens mineral i marts er beryl - her den grønne varietet smaragd fra Cozques, Colombia. Motiv: 20 x 30 mm. (Foto: Ole Johnsen, Geologisk Museum)

Af Ulla V. Hjuler, GeologiskNyt

I februar kunne besøgende på Geologisk Museum i København glæde sig over synet af de mange fine fluoritter, der var udstillet. I marts er månedens mineral beryl, og de udstillede stykker er bestemt også værd at kigge nærmere på.
Beryl er rigtigt samlermineral. De farvestrålende varieteter er eftertragtede og meget anvendte i smykkeindustrien på grund af deres skønhed. Mineralet er almindeligt forekommende og samtidig den vigtigste kommercielle kilde til grundstoffet beryllium.

\section{Strukturen}

Det mest fremherskende træk ved beryls krystalstruktur er de hexagonale ringe bestå-

\section{Udvalgte egenskaber}

Kemi: $\mathrm{Be}_{3} \mathrm{Al}_{2} \mathrm{Si}_{6} \mathrm{O}_{18}$

Krystallografi: Hexagonal. Prismatiske krystaller

Hårdhed Mohs: 71/2-8

Massefylde: ca. 2,7 g/ $\mathrm{cm}^{3}$

Streg: Hvid

Spaltelighed: $\{0001\}$ - dårlig

Farve: Rød, blå, gul, grøn, farveløs, rosa

Brud: Muslet og ujævnt
Transparens: Transparent, translucent til opak

Andet: Beryl er det mest almindelige berylliummineral og den vigtigste kommercielle kilde til grundstoffet beryllium

Forekomst: Bl.a. Columbia, Indien, Brasilien, Norge, Australien, Rusland, Sydafrika, Burma, Madagascar, Californien ende af seks $\mathrm{SiO}_{4}$-tetraedre. Disse $\left[\mathrm{Si}_{6} \mathrm{O}_{18}\right]$ ringe ligger oven på hinanden og danner lange, hule kanaler, der er parallelle med c-aksen. I hver af ringene deles to af ilt-atomerne i hver $\mathrm{SiO}_{4}$-gruppe med $\mathrm{SiO}_{4}$-grupperne på hver side. Mellem ringene befinder aluminium- og beryllium-atomerne sig.

\section{Varieteterne}

Berylgruppen dækker over farvevarieteterne akvamarin, smaragd, morganit, heliodor og bixbit. En "ren" beryl er farveløs og kaldes også goshenit.

\section{Akvamarin}

Akvamarinen er grønlig til blålig (se fx forsidefotoet). Den blå farve kan skyldes, at der indbygges jern $\left(\mathrm{Fe}^{2+} / \mathrm{Fe}^{3+}\right)$ i ringstrukturen på de oktaedriske Al-pladser, på de meget små Be-pladser eller i kanalerne (parallelle med c-aksen - se figur), der er dannet af $\left[\mathrm{Si}_{6} \mathrm{O}_{18}\right]$-ringe. Ved opvarmning til over $400{ }^{\circ} \mathrm{C}$ skifter akvamarinen farve fra søgrøn til himmelblå.

\section{Smaragd}

Smaragdens dybgrønne farve skyldes indbygning af $\mathrm{Cr}_{2} \mathrm{O}_{3}$ i strukturen. En mindre mængde af de oktaedrisk koordinerede Al- 


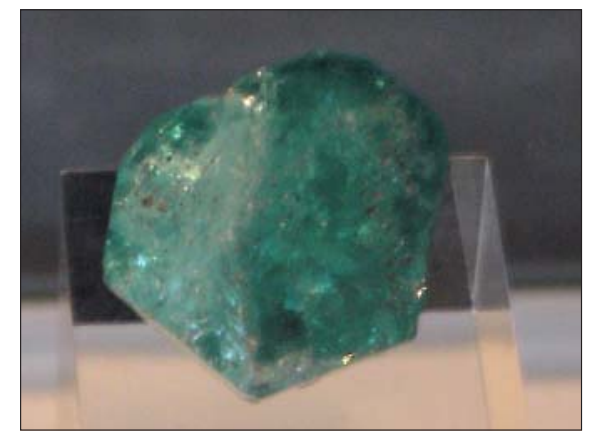

På udstillingen kan bl.a. denne smaragd fra den kendte smaragdforekomst Muzo i Colombia ses. (Foto: Jan Thøgersen)

atomer erstattes af Cr. Denne substitution er mulig, fordi begge ioner har samme ladning $\left(\mathrm{Cr}^{3+}\right.$ og $\left.\mathrm{Al}^{3+}\right)$ og radius. Ved opvarmning til over $800{ }^{\circ} \mathrm{C}$ ændres farven.

\section{Heliodor eller guldberyl}

Den gule farve skyldes substitution af små mængder $\mathrm{Fe}^{3+}$ for oktaedrisk koordineret $\mathrm{Al}^{3+}$. Ved opvarmning til omkring $250{ }^{\circ} \mathrm{C}$ mister guldberyllen sin farve.

\section{Morganit}

Den lyserøde beryls farve skyldes mangan eller cæsium. En svagt rosafarvet morganit kan ved opvarmning til over $400{ }^{\circ} \mathrm{C}$ få en kraftigere farve.

\section{Bixbit}

Den røde beryl antages at få sin farve ved substitution af mangan $\left(\mathrm{Mn}^{2+}\right)$ for aluminium. Denne varietet er ret sjælden og forekommer aldrig i store krystaller.

\section{Forekomst}

Beryl forekommer ofte i granitter og pegmatitter. Beryls tilstedeværelse i granitiske pegmatitter skyldes berylliums størrelse - Be-ionen, som generelt er for lille til at substituere for andre kationer i silikatstrukturer, er koncentreret i residualmagmatiske fluider (residual = rest). Beryl ses sjældnere i nefelin-syenitter, i glimmerskifre og marmor. Smaragder er primært begrænset til metamorfe parageneser - typisk i biotitskifre - eller i calcitårer i bituminøse (kulbrinteholdige) kalksten som i den kendte forekomst i Muzo, Columbia. Brasilien huser nogle af de største berylforekomster i ædelstenskvalitet i verden.

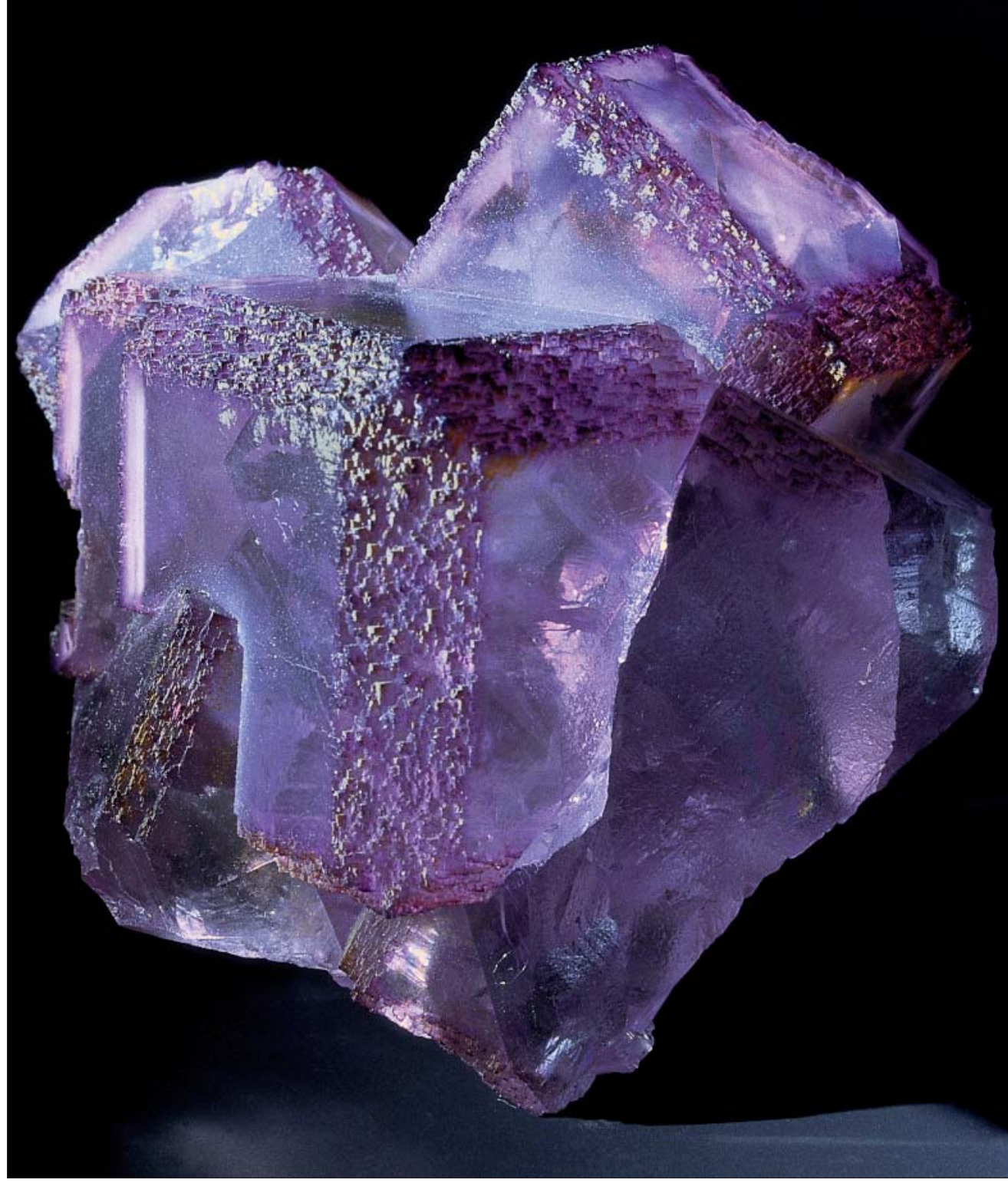

Månedens mineral i februar var fluorit - her en lilla fluorit fra La Collada, Asturien, Spanien. Motiv: 60 × 64 mm. (Foto: Ole Johnsen, Geologisk Museum)

I april og maj måned kan besøgende glæde sig til at se hhv. anhydrit og galenit

\section{Referencer:}

Johnsen, O., 2000. Mineralernes verden. Gads Forlag

Schumann, W., 1993. Edelstene. Gads Forlag

Steffen, G., 2000. Farbe und Luminiszenz von Mineralien. Enke im Georg Thieme Verlag
Beryl er hexagonal. De karakteristiske ringe ses illustreret vha. de røde trekanter. Ringene ligger oven på hinanden og danner lange kanaler. På det lille billede nederst er aksesystemet vist - c-aksen er vinkelret på papirets plan. (Grafik: Forfatteren)

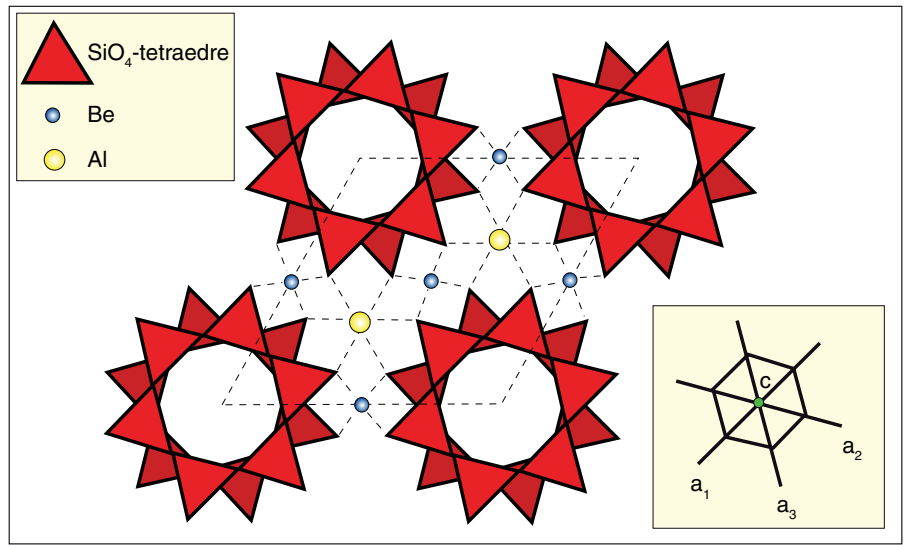

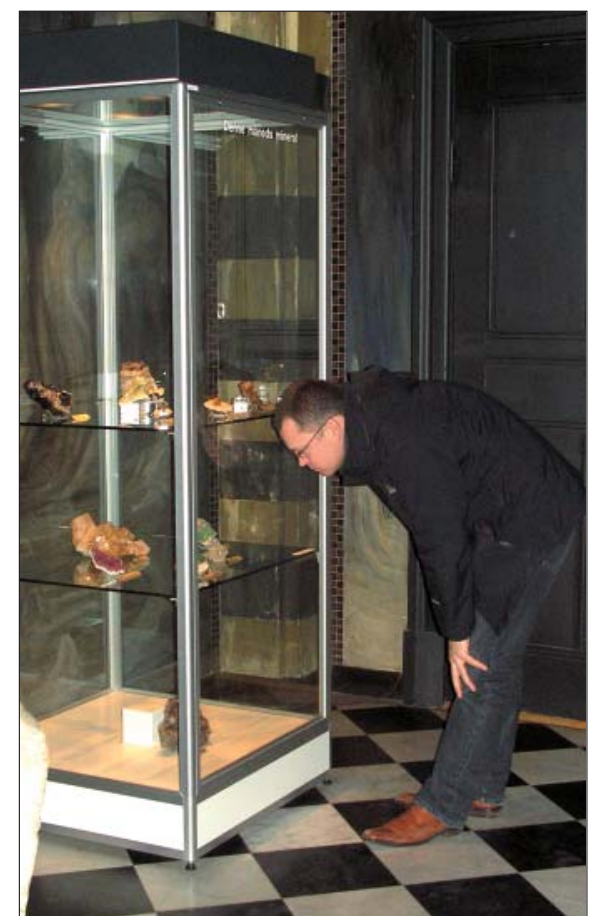

Månedens mineral i februar - fluorit. De flotte stykker betragtes indgående. (Foto: Forfatteren) 